\title{
Tema: Mindfulness
}

Størstedelen af dette nummer af Religionsvidenskabeligt Tidsskrift er viet temaet Mindfulness - et hastigt voksende fænomen i den vestlige verden, også i Danmark. En søgning på begrebet i Infomedia viser 499 hits i den 20-årige periode fra 1990 til 2009, mens der de sidste fire år er ti gange så mange (5.024). Et temanummer af Contemporary Buddhism fra 2011 viser en eksponentiel stigning de sidste få år, med omkring 350 artikler i 2010; flere af disse er sikkert relateret til de 150 forskningsprojekter, som National Institute of Health havde sponsoreret til feltet på bare fem år. Boghandlere, livsstilsmagasiner og dameblade viser, at fænomenet strækker sig langt ud over de videnskabelige rammer. Erhvervslivet afholder kurser i mindfulness. Der er mindfulness i fængsler, militær, skoler og hospitaler; snart kommer der et Center for Mindfulness på Aarhus Universitet. Psykologer og terapeuter bruger mindfulness, og en kristen version ('Christfulness') har set dagens lys som alternativ til de kirker og kristne grupper, der også bruger teknikken. Mindfulness er en praksis og et brand, en filosofi og big business.

Hvor retoucheret oprindelsen end måtte være, er der en klar tråd til buddhismen. Mindfulness er en engelsk oversættelse af paliordet sati (jf. sanskrit smrti), der kan oversættes med 'årvågenhed', 'opmærksomhed'. I buddhistisk praksis er sati som 'korrekt opmærksomhed' (samma-sati) det syvende led i den Ottefoldige Vej. Her er det udtryk for en konkret meditationsform, der især er forbundet med indsigt (vipassana), i sig selv et unikt buddhistisk aspekt, som skal forstås som 'overbygning' til koncentration (samatha). Meditation på åndedrættet, på kroppen eller på bevidstheden er ideelt set ikke (kun) teknik til fokuseret koncentration, men også meditativ eksistenserkendelse. I bredere forstand er mindfulness derfor også et generelt perspektiv på ret buddhistisk levevis. Det er en ideel bevidstheds- og eksistensform, der overordnet set er det filterløse vue, en buddhist erkender sig selv og eksistensen med, og som derfor også bør flyttes uden for meditationssalen. Sati er traditionelt del af en ritualiseret, religiøs klostertradition. At sati også kan oversættes som 'hukommelse' eller 'erindring', understreger yderligere oprindelsen i den religiøse tradition. Denne er ofte negligeret i vestlige kontekster, hvor mindfulness typisk anvendes som en teknik for det autonome individ.

Mindfulness i dens moderne, vestlige udgave er især relateret til traditionen omkring Jon Kabat-Zinn. I 1979 grundlagde han på University of Massachusetts programmet Mindfulness-Based Stress Reduction, og med talrige publikationer, eksperimenter og kurser har den vestlige, psykologiske mindfulness med ham og hans 
mange kolleger fået sin helt egen tradition. Mindfulness har været anvendt til behandling af stress, angst, depression og i bredere forstand til konstruktion af mental helse, ikke mindst som del af den kognitive adfærdsterapi og psykologiens 'tredje kognitive bølge'. Kabat-Zinn og mange andre af disciplinens udøvere er selv i en eller anden forstand buddhister. Men vestlig mindfulness er ofte rekonstrueret som spiritualitet eller sekulariseret individualisme. Religionshistorisk og religionssociologisk er emnet interessant som udtryk for religiøs transformation. Det er et oplagt emne til interdisciplinær forskning, der inkluderer bl.a. antropologi og psykologi. Sundhedsvidenskabelig forskning vil søge efter, om mindfulness virker; og kulturvidenskabelig forskning vil undersøge mindfulness' betydning.

Den interdisciplinære interesse var rammen for en workshop om mindfulness i efteråret 2011, arrangeret i fællesskab mellem forskningsprojektet Buddhism and modernity og Center for Samtidsreligion ved Aarhus Universitet. Flere af bidragene er samlet til dette nummer i Religionsvidenskabeligt Tidsskrift. Sita Kotnis beskriver anvendelsen af mindfulness i det amerikanske militær. Ud fra sit feltarbejde diskuterer hun den kontroversielle relation mellem kontemplativ praksis og krigsførelse. Katarina Plank undersøger mindfulness i Sverige ud fra tre felter: terapeutiske, kommercielle og religiøse. Hun konkluderer, at mindfulness især findes uden for religiøse kontekster, og reflekterer over dets andel i en mulig transformation fra religion til åndelighed. Rikke Gottfredsens artikel belyser udbuddet af mindfulness på nettet i en konkret, lokal ramme (Aarhus). Ligesom Plank konkluderer hun, at mindfulness oftest præsenteres i videnskabelige termer som en sekulær teknik. Peter Elsass' bidrag (skrevet sammen med elleve medforfattere) omhandler et konkret forsøg med 63 kræftsyge kvinder og deres selvrepræsentation efter erfaring med mindfulness. Forsøget viste klart positive effekter, men også, at referencen til spiritualitet var meget sparsom. Alle bidrag viser således, at den 'buddhistiske' mindfulness i Vesten primært anvendes uden for dens religiøse kontekst som en spirituel eller sekulær teknik i sekulære rum.

Indskudt imellem tema-artikler og anmeldelse indeholder dette nr. 61 desuden tre bidrag. Peter Lüchau argumenterer for, at sekulariseringsteorien fortsat er plausibel, i hvert fald for danske forhold. Katrine Frøkjær Baunvig, fra og med dette nummer medredaktør, oversætter og indleder til et vigtigt foredrag af Emile Durkheim, 100 år efter. Og Anders Klostergaard Petersen vurderer to bind af den nye Platonoversættelse.

Jørn Borup, lektor, ph.d., E Hans J. Lundager Jensen, professor, dr. theol. Religionsvidenskab, Aarhus Universitet 